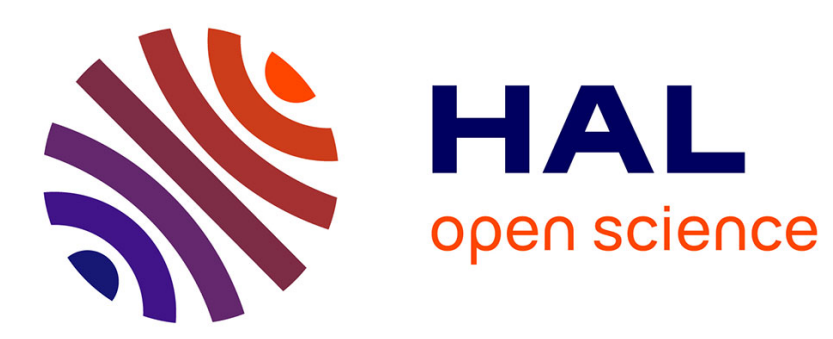

\title{
Pro-opiomelanocortin (POMC)-derived peptides and the regulation of energy homeostasis
}

\author{
Anthony P. Coll, Y.C. Loraine Tung
}

\section{To cite this version:}

Anthony P. Coll, Y.C. Loraine Tung. Pro-opiomelanocortin (POMC)-derived peptides and the regulation of energy homeostasis. Molecular and Cellular Endocrinology, 2009, 300 (1-2), pp.147. 10.1016/j.mce.2008.09.007 . hal-00532076

\section{HAL Id: hal-00532076 https://hal.science/hal-00532076}

Submitted on 4 Nov 2010

HAL is a multi-disciplinary open access archive for the deposit and dissemination of scientific research documents, whether they are published or not. The documents may come from teaching and research institutions in France or abroad, or from public or private research centers.
L'archive ouverte pluridisciplinaire HAL, est destinée au dépôt et à la diffusion de documents scientifiques de niveau recherche, publiés ou non, émanant des établissements d'enseignement et de recherche français ou étrangers, des laboratoires publics ou privés. 


\section{Accepted Manuscript}

Title: Pro-opiomelanocortin (POMC)-derived peptides and the regulation of energy homeostasis

Authors: Anthony P. Coll, Y.C. Loraine Tung

PII: $\quad$ S0303-7207(08)00404-8

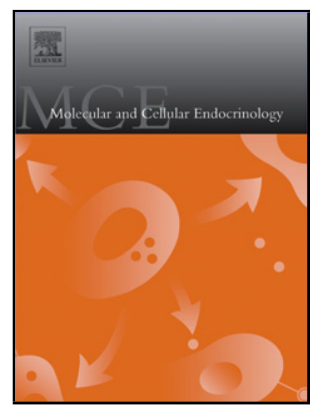

DOI: doi:10.1016/j.mce.2008.09.007

Reference: MCE 6976

To appear in: Molecular and Cellular Endocrinology

Received date: $17-7-2008$

Revised date: $3-9-2008$

Accepted date: 8-9-2008

Please cite this article as: Coll, A.P., Tung, Y.C.L., Pro-opiomelanocortin (POMC)derived peptides and the regulation of energy homeostasis, Molecular and Cellular Endocrinology (2008), doi:10.1016/j.mce.2008.09.007

This is a PDF file of an unedited manuscript that has been accepted for publication. As a service to our customers we are providing this early version of the manuscript. The manuscript will undergo copyediting, typesetting, and review of the resulting proof before it is published in its final form. Please note that during the production process errors may be discovered which could affect the content, and all legal disclaimers that apply to the journal pertain. 


\title{
Pro-opiomelanocortin (POMC)-derived peptides and the regulation of energy homeostasis
}

\author{
Anthony P. Coll ${ }^{\text {** }}$ and Y. C. Loraine Tung
}

University of Cambridge Metabolic Research Laboratories, Institute of Metabolic Science, Addenbrooke's Hospital, Cambridge CB2 0QQ, UK.

*Corresponding author:

Anthony P Coll apc36@,cam.ac.uk

University of Cambridge Metabolic Research Laboratories

Institute of Metabolic Science, Level 4

Addenbrooke's Hospital Box 289

Cambridge CB2 OQQ

Tel -44-1223-769041

Fax -44-1223-330598 


\begin{abstract}
Human genetic data indicate impaired synthesis or processing of POMC results in obesity. We have used a mouse model of POMC deficiency (Pomc null) to explore the role of POMC-derived peptides in energy homeostasis. The phenotype of Pomc null mice recapitulates the clinical syndrome seen in humans congenitally lacking POMC. Loss of only one copy of the Pomc gene is sufficient to render mice susceptible to the effects of high fat feeding, emphasizing an important gene-environment interaction predisposing to obesity. Our studies indicate that POMC-derived peptides have influences on the response to a high fat diet, including a major influence on the dietary preference for fat. Pomc-null mice are unusual in that obesity and hyperphagia develop in the absence of circulating glucocorticoid (GCs). To investigate the interaction between GCs and the melanocortin system, we administered corticosterone to Pomc null mice. They appear hypersensitive to the adverse metabolic effects of GCs, developing hypertension, an exacerbation of both hyperphagia and obesity and a profound insulin resistance. GC treatment of Pomc null mice significantly increases the expression of the melanocortin antagonist agouti-related protein (AgRP). On-going studies in mice lacking both Agrp and Pomc will determine whether the metabolic phenotype seen with this GC therapy is due to a lack of melanocortin peptide, the unopposed action of AgRP or a combination of both.
\end{abstract}




\section{The central melanocortin system and energy balance}

The central nervous system (CNS) is firmly placed as a central player in the homeostatic mechanisms which control food intake and energy expenditure (1). Our current understanding of these pathways is due to extensive data from rodent models, exemplified in the case of the leptin-melanocortin system. Right across this pathway genetically modified rodents - both specifically engineered and spontaneously occurringhave illuminated the workings of this system. Telling insights have also arisen from human genetic studies which combine with these rodent data in a powerful synergistic manner.

\section{Global POMC deficiency}

\section{Human}

The clear role of POMC in energy balance was shown with the first description in 1998 of two children congenitally lacking POMC gene products (2). One proband was a compound heterozygote for two nonsense mutations in exon 3. A second patient was homozygous for a 5'-untranslated region mutation that introduced an additional out-offrame start site, thus interfering with $P O M C$ translational initiation. As a consequence of ACTH deficiency, both subjects presented in early childhood with the metabolic consequences of hypocortisolaemia. Both went on to develop severe, early-onset obesity associated with hyperphagia (due to reduced hypothalamic melanocortinergic signaling) and both probands had pale skin and red hair (the result of reduced signaling through MC1R on melanocytes in skin and hair follicles). This group has gone on to report three additional children with an identical phenotype (3). However, in 2006 colleagues in Cambridge reported a child of Turkish origin with severe obesity and hypoadrenalism (4). This proband was the first patient reported with POMC deficiency who did not have red hair. This difference may be as a result of the genetic background (Turkish) differing from the other reported cases who were all white Caucasian subjects of European ancestry. The retention of dark, eumelanin -rich hair in this child indicates that eumelanin synthesis in humans has no absolute requirement for melanocortin peptides. This works mirrors the findings by Low and colleagues, whose report of preservation of eumelanin hair pigmentation in Pomc-null mice on a non-agouti $(a / a)$ genetic background 
had previously indicated that genetic background was critical for determining the pigment phenotype of POMC deficiency (5).

\section{Mouse}

The first report of a mouse model with disruption of both alleles of the POMC gene (6) recapitulated the phenotype seen in humans, indicating that melanocortin pathways in humans and rodents subserve similar physiological functions. We have studied a second, independent line of mice lacking all POMC-derived peptides that are markedly obese, hyperphagic and have both altered pigmentation and adrenal insufficiency (7). This increase in weight results from an increase in both fat and lean mass. Additionally, Pomc mice have a lower basal metabolic rate than their wild type litter mates, which may be due to reduced activity of the hypothalamic-pituitary-thyroid axis (7). More recently, $\mathrm{Xu}$ et al. have generated a further corticosterone-deficient mouse model of POMC deficiency by deletion of the critical mitochondrial transcription factor, Tfam, from POMC expressing cells (8). These mice exhibited a progressive adult-onset obesity with an increase in both fat and lean mass.

\section{$\alpha-, \beta-$ and $\gamma$-MSH : unique, overlapping or redundant?}

POMC is a polypeptide precursor which undergoes extensive post-translational modification to release biologically active, smaller fragments. These include ACTH and $\alpha-, \beta$ - and $\gamma-\mathrm{MSH}$, collectively known as the melanocortins (Fig 1).

Given the complexity of the POMC deficiency syndrome, it is important to determine which part(s) of the missing polypeptide are responsible for each facet of the phenotype and whether melanocortins have unique, overlapping or redundant roles within the hypothalamus. The study of this region of the brain in humans is challenging but a murine model offers a more tractable system in which to try and address such questions. We compared the effects upon food intake and body weight of melanocortins given intracerebroventricularly (icv) to our Pomc $^{-1-}$ model (9). Of the peptides administered, $\alpha$-MSH brought about the biggest reduction in food intake. This melanocortin was the only peptide able to reduce the excess fat and lean mass found in $\mathrm{Pomc}^{-/-}$mice. On the 
basis of pair- feeding experiments, these effects of $\alpha-\mathrm{MSH}$ were mediated primarily through a reduction in food intake.

However, useful as rodent models are, there may be more to learn. One inherent weakness in using these animals to gain physiological knowledge of the melanocortins is that rodents lack the N-terminal cleavage site necessary for the generation of $\beta$-MSH and this is not an endogenous ligand in mice. Therefore murine studies are likely to be biased to favouring $\alpha-\mathrm{MSH}$ above $\beta$-MSH in the melanocortin hierarchy.

It has required human genetic studies to bring novel insights into the function of $\beta$-MSH with two recent publications suggesting this melanocortin may play a role in the hypothalamic control of body weight in humans. Lee and colleagues (10) screened the POMC gene in 538 patients with severe, early-onset obesity and identified five unrelated probands who were heterozygous for a rare missense variant in the region encoding $\beta$ MSH, Tyr221Cys. The variant co-segregated with obesity in affected family members. Of note, it was also found in 1/300 non-obese UK Caucasian adults and in 3 of 4,852 subjects from an unselected UK Caucasian population. However, in vitro studies of the mutant $\beta$-MSH demonstrated that it had impaired ability to bind to and activate signaling at the MC4R, supporting the idea that mutant $\beta$-MSH was contributing to the obesity in affected individuals.

In the same journal Biebermann reported an identical missense mutation within POMC (11). The Y5C- $\beta-M S H$ mutation was found in obese family members of the index child but because other family members who were also overweight did not carry the mutation, it cannot be considered to be the sole cause for obesity in the studied family. Biebermann et al. went on to show that the mutant $\beta$-MSH peptide was functionally inert, having no effect upon food intake when administered icv to rats. They also used immunohistochemistry in postmortem sections to demonstrate that $\beta$-MSH is expressed in POMC neurons in the human arcuate nucleus, adding a detailed distribution pattern of $\beta$-MSH in human hypothalamus that had not been previously reported. 


\section{Glucocorticoids and melanocortins}

Pomc null mice are unusual among murine models of disordered energy homeostasis in that obesity develops in the absence of circulating glucocorticoids (GC). GCs have pleiotropic effects on metabolism with changes in circulating levels of GC able to impact upon the melanocortin system. For example, adrenalectomy is able to reverse the obese phenotype and restore hypothalamic melanocortin tone in leptin-deficient $o b / o b$ mice (12). In addition, adrenalectomy alters the sensitivity of the central melanocortin system to the effects of the melanocortin antagonist AgRP, with the orexigenic effect of this peptide being absent in adrenalectomised rats but restored with GC supplementation (13). Thus many features of the Pomc null phenotype may be significantly influenced by the lack of circulating glucocorticoid.

We analysed the phenotype of POMC deficient mice who had received cortisosterone supplemented drinking water $(25 \mu \mathrm{g} / \mathrm{ml}$ final concentration), herein referred to as "CORT" (14). When mice were given CORT from weaning, although by 8 weeks the trajectory of their growth curve began to rise above that of control mutant littermates, by 10 weeks CORT-treated mice were losing weight. The fall off in body weight and body length seen in CORT treated Pomc ${ }^{-/}$mice was accompanied by a progressive rise in blood glucose such that by 12 weeks old animals became frankly diabetic with polyuria and ketonuria. These mice were also markedly polydipsic, drinking over 3 times as much as CORT treated wild type mice.

We subsequently studied the effects of just 10 days of CORT treatment in wild type and Pomc null mice(14). Although plasma corticosterone and CRH mRNA expression were similar in both genotypes, the impact upon the phenotypes exhibited was markedly different. In particular, only Pomc ${ }^{-/}$mice significantly increased their body weight due entirely to increased fat accumulation. As expected, this increase in fat mass was accompanied by an increase in plasma leptin levels. CORT treatment also caused an increase in plasma leptin levels in wild type animals, despite there being no change in fat mass. This may be a reflection of the previously reported direct effect glucocorticoids have on leptin, increasing both expression within and secretion from adipocytes (15). 
CORT treatment affected food intake in $\mathrm{Pomc}^{-/}$mice only, accentuating the established hyperphagia seen in these mice. Analysis of orexigenic peptide expression within the hypothalamus gave insights into the potential mechanisms underlying this. The differences in $A g R P$ mRNA expression were most striking. Corticosterone-deplete Pomc $^{-/}$mice had less than half the expression level seen in wild type mice. GC treatment to Pomc ${ }^{-/}$mice restored Agrp expression back to levels seen in wild type mice but drove food intake far higher than that seen in wild type mice. One potential explanation may lie in that fact that AgRP has been proposed to be an inverse agonist in addition to an antagonist at MC4R $(16,17)$. In contrast to intact wild type animals Pomc ${ }^{-/}$mice do not produce any anorexigenic melanocortin peptides to act as agonist at MC4-Rs, leaving the orexigenic, inverse-agonist effect of AgRP unopposed. A further increase in AgRP levels following GC treatment therefore is manifest as an even greater increase in food intake.

To investigate further the peripheral mechanisms underlying this apparent glucocorticoid hypersensitivity, in collaboration with colleagues in Edinburgh we went on to examine the expression levels of a number of key determinants and targets of glucocorticoid action in adipose tissue and liver (18). We determined that despite lower basal expression of $11 \beta$ hydroxysteroid dehydrogenase type 1 (11ß-HSD1), which generates active glucocorticoids within cells, CORT-mediated induction of $11 \beta-H S D 1$ mRNA levels was more pronounced in adipose tissues of Pomc $^{-/-}$mice. Similarly, CORT treatment increased lipoprotein lipase mRNA levels in all fat depots in Pomc ${ }^{-/-}$mice, consistent with the exaggerated fat accumulation seen.

The Low laboratory in Oregon have used a genetic approach to "rescue" pituitary POMC activity in $\mathrm{Pomc}^{-/-}$mice (19). By introducing a POMC transgene that selectively restored peripheral melanocortin and therefore corticosterone secretion in $\mathrm{Pomc}^{-/-}$mice $\left(\mathrm{Pomc}^{-/-}\right.$ $\mathrm{Tg}^{+}$) they were able to create a "de facto" neuronal POMC deficiency. In such Pomc $\mathrm{Tg}^{+}$mice a diurnal pattern of corticosterone was restored, albeit to a somewhat exaggerated extent with plasma levels ranging between 50 and $220 \mathrm{ng} / \mathrm{ml}$ in male mice. The resulting phenotype was very similar to that of corticosterone-treated $\mathrm{Pomc}^{-/-}$mice. Restoration of peripheral POMC expression in $\mathrm{Pomc}^{-/} \mathrm{Tg}^{+}$significantly worsened the 
hyperphagia and obesity of the mice and was characterised by a marked increase in white adipose tissue, massive hepatic steatosis, hyperleptinaemia and insulin resistance. Despite these data, it remains unclear if the severe metabolic consequences revealed when Pomc $^{-/}$mice are treated with corticosterone are driven by an AgRP-dependent mechanism. To answer this we have generated a "double knockout" lacking both AgRP and POMC peptides $\left(\mathrm{Agrp}^{-/-} ; \mathrm{Pomc}^{-/}\right)$and analysis of this mouse model is currently ongoing ( AP Coll \& YCL Tung, unpublished observations).

\section{POMC and dietary macronutrients- a gene-environment interaction}

There is evidence of genetic variation in molecules of the melancortin system on quantitative human traits. The region of human chromosome 2 containing the POMC gene has been implicated as a susceptibility locus for common human obesity $(20,21)$. Results from a genome-wide scan using data from the San Antonio Family Heart Study (SAFHS) suggest that this chromosomal region might contribute to dietary macronutrient intake and adiposity phenotypes in Mexican Americans (22).

We have used Pomc null mice to determine how Pomc haploinsufficiency might interact with changes in dietary composition.

On standard chow, only homozygous mutant mice became obese, with $P o m c^{+/-}$mice achieving an adult weight similar to that of wild-type mice(7). However, with high fat feeding ( $45 \%$ fat), Pomc ${ }^{+/-}$mice also became obese. At 6 months of age heterozygous mice weighed $20 \%$ more than wild type littermates, whose weight remained unaffected by the high fat diet. The development of obesity in Pomc insufficient mice on a high fat was the result of increased energy intake, with $\mathrm{Pomc}^{-/-}$and $\mathrm{Pomc}^{+/-}$eating $40 \%$ and $18 \%$ more than wild type mice, respectively. This observation demonstrates that under certain environmental conditions, a single functional copy of the Pomc gene is not sufficient for maintaining normal energy homeostasis. Additional evidence for this hypothesis comes from the findings that none of the 10 adults heterozygous for $P O M C$ mutations reported by Krude et al. had a low normal BMI value, with body weight in heterozygous mutation carriers shifted to the high normal +1 BMI-SDS or even overweight range of +2 BMISDS (3). Further, the diagnosis of the Turkish POMC null proband highlighted above 
gave the opportunity to study a large extended pedigree and address whether loss of one copy of the $P O M C$ gene was sufficient to alter obesity risk(4). Twelve relatives were heterozygous for the mutation and 7 were wild type. Of the heterozygotes, 11 of 12 heterozygotes were obese or overweight compared with only 1 of 7 of the wild-type relatives. The mean BMI SD score was $1.7 \pm 0.5$ in heterozygotes and $0.4 \pm 0.4$ in the wild-type relatives. Thus POMC haploinsufficiency may shift the individual body weight to higher normal or mildly obese level.

There are also data suggesting that perturbations in melanocortin signaling can impact upon feeding behaviour by modulating macronutrient choice. Increased antagonism at MC4R receptors, either brought about pharmacologically by icv administration of AgRP or as a result of ectopic production of Agouti in the case of obese $A^{y} / a$ mice, results in a preferential consumption of fat $(23,24)$. In contrast, administration of the potent melanocortin agonist MTII can cause a reduction in fat consumption(25).

We studied macronutrient preference of Pomc insufficient mice to explore further the interactions between dietary composition and Pomc genotype(26). Given ad libitum access to a three-choice buffet of food pellets containing 10, 45 or $60 \%$ fat, both $\mathrm{Pomc}^{+/-}$ and Pomc null mice preferentially consumed diet with a higher fat content. In a separate buffet test using three foodstuffs of near pure macronutrient content (fat, protein or carbohydrate) there was a clear gene dosage effect on fat consumption with homozygous null and heterozygous mice eating $98 \%$ and $45 \%$ more fat than wild type mice, respectively (Fig $2 \mathrm{~A}$ ). We studied fat consumption in a third experiment, in which a highly palatable mix of sweetened condensed milk and $45 \%$ fat $(500 \mathrm{mls}$ milk per $\mathrm{kg}$ of high fat diet(27)) was offered to the mice in addition to high fat diet. Thus "Menu 1" consisted of the 10, 45 or $60 \%$ fat as previous whilst in "Menu 2", the $10 \%$ fat was replaced by the sweetened milk/fat diet (Fig 2 B). When offered this alternative palatable option, wild type mice switched preference and reduced the amount of $60 \%$ fat consumed; in contrast, Pomc insufficient mice still preferentially consumed 60\% fat (Fig 2B). 
In terms of energy expenditure, Pomc null mice also showed a different response to wild type mice when challenged with a high fat $\operatorname{diet}(26)$. When fed a $60 \%$ fat diet, wild type mice increased their ambulatory activity by close to $50 \%$ and their rearing behaviour near 4-fold compared to activity levels on standard chow. This was in contrast to Pomc null mice, whose activity levels remained entirely unchanged from those seen on standard chow.

Thus POMC-derived peptides have influences on multiple aspects of the organism's response to the external diet. This includes a major influence, readily discernible even in heterozygote animals, on the dietary preference for fat. The cumulative impact of these perturbations results in substantial weight gain when a high fat diet is available, highlighting an important gene-environment interaction and supporting the hypothesis that genetic variation around the Pomc locus confers a risk for developing obesity.

\section{Conclusions}

Our current knowledge of the central melanocortin signaling pathway bears testament to the utility of combining human genetic studies with murine modeling as a way of understanding complex systems biology. However, there is still much to learn. Simple pharmacological replacement studies can never hope to replicate the inherent beauty and complexity of POMC processing which is undoubtedly at work within the hypothalamus. More subtle genetic manipulation than a global knockout will be required to parse out the fine detail of this system. The true physiological role of AgRP and in particular its mysterious $\mathrm{N}$-terminal portion also remains elusive. The melanocortin story also continues to evolve with the tantalizing recent discovery that $\beta$-defensins, a family of proteins previously implicated in innate immunity, are now a novel class of ligands signalling through melanocortin receptors(28). Whether these molecules do play a significant role in mammalian energy homeostasis remains to be determined but these novel findings tell us that we are far from knowing all we need to know about the melanocortin system. 


\section{$\underline{\text { References }}$}

1. Coll AP, Farooqi IS, O'Rahilly S 2007 The hormonal control of food intake. Cell 129:251-62

2. Krude H, Biebermann H, Luck W, Horn R, Brabant G, Gruters A 1998 Severe early-onset obesity, adrenal insufficiency and red hair pigmentation caused by POMC mutations in humans. Nat Genet 19:155-7

3. Krude H, Biebermann H, Schnabel D, Tansek MZ, Theunissen P, Mullis PE, Gruters A 2003 Obesity due to proopiomelanocortin deficiency: three new cases and treatment trials with thyroid hormone and ACTH4-10. J Clin Endocrinol Metab 88:4633-40

4. Farooqi IS, Drop S, Clements A, Keogh JM, Biernacka J, Lowenbein S, Challis BG, O'Rahilly S 2006 Heterozygosity for a POMC-null mutation and increased obesity risk in humans. Diabetes 55:2549-53

5. Smart JL, Low MJ 2003 Lack of proopiomelanocortin peptides results in obesity and defective adrenal function but normal melanocyte pigmentation in the murine C57BL/6 genetic background. Ann N Y Acad Sci 994:202-10

6. Yaswen L, Diehl N, Brennan MB, Hochgeschwender U 1999 Obesity in the mouse model of pro-opiomelanocortin deficiency responds to peripheral melanocortin. Nat Med 5:1066-70

7. Challis BG, Coll AP, Yeo GS, Pinnock SB, Dickson SL, Thresher RR, Dixon J, Zahn D, Rochford JJ, White A, Oliver RL, Millington G, Aparicio SA, Colledge WH, Russ AP, Carlton MB, O'Rahilly S 2004 Mice lacking proopiomelanocortin are sensitive to high-fat feeding but respond normally to the acute anorectic effects of peptide-YY(3-36). Proc Natl Acad Sci U S A 101:4695700

8. Xu AW, Kaelin CB, Morton GJ, Ogimoto K, Stanhope K, Graham J, Baskin DG, Havel P, Schwartz MW, Barsh GS 2005 Effects of hypothalamic neurodegeneration on energy balance. PLoS Biol 3:e415

9. Tung YC, Piper SJ, Yeung D, O'Rahilly S, Coll AP 2006 A comparative study of the central effects of specific proopiomelancortin (POMC)-derived melanocortin peptides on food intake and body weight in pomc null mice. Endocrinology 147:5940-7

10. Lee YS, Challis BG, Thompson DA, Yeo GS, Keogh JM, Madonna ME, Wraight V, Sims M, Vatin V, Meyre D, Shield J, Burren C, Ibrahim Z, Cheetham T, Swift P, Blackwood A, Hung CC, Wareham NJ, Froguel P, Millhauser GL, O'Rahilly S, Farooqi IS 2006 A POMC variant implicates betamelanocyte-stimulating hormone in the control of human energy balance. Cell Metab 3:135-40

11. Biebermann H, Castaneda TR, van Landeghem F, von Deimling A, Escher F, Brabant G, Hebebrand J, Hinney A, Tschop MH, Gruters A, Krude H 2006 
A role for beta-melanocyte-stimulating hormone in human body-weight regulation. Cell Metab 3:141-6

12. Makimura H, Mizuno TM, Roberts J, Silverstein J, Beasley J, Mobbs CV 2000 Adrenalectomy reverses obese phenotype and restores hypothalamic melanocortin tone in leptin-deficient ob/ob mice. Diabetes 49:1917-23

13. Drazen DL, Wortman MD, Schwartz MW, Clegg DJ, van Dijk G, Woods SC, Seeley RJ 2003 Adrenalectomy alters the sensitivity of the central nervous system melanocortin system. Diabetes 52:2928-34

14. Coll AP, Challis BG, Lopez M, Piper S, Yeo GS, O'Rahilly S 2005 Proopiomelanocortin-deficient mice are hypersensitive to the adverse metabolic effects of glucocorticoids. Diabetes 54:2269-76

15. Slieker LJ, Sloop KW, Surface PL, Kriauciunas A, LaQuier F, Manetta J, Bue-Valleskey J, Stephens TW 1996 Regulation of expression of ob mRNA and protein by glucocorticoids and cAMP. J Biol Chem 271:5301-4

16. Haskell-Luevano C, Monck EK 2001 Agouti-related protein functions as an inverse agonist at a constitutively active brain melanocortin-4 receptor. Regul Pept 99:1-7

17. Nijenhuis WA, Oosterom J, Adan RA 2001 AgRP(83-132) acts as an inverse agonist on the human-melanocortin-4 receptor. Mol Endocrinol 15:164-71

18. Michailidou Z, Coll AP, Kenyon CJ, Morton NM, O'Rahilly S, SeckI JR, Chapman KE 2007 Peripheral mechanisms contributing to the glucocorticoid hypersensitivity in proopiomelanocortin null mice treated with corticosterone. J Endocrinol 194:161-70

19. Smart JL, Tolle V, Low MJ 2006 Glucocorticoids exacerbate obesity and insulin resistance in neuron-specific proopiomelanocortin-deficient mice. J Clin Invest 116:495-505

20. Comuzzie AG, Hixson JE, Almasy L, Mitchell BD, Mahaney MC, Dyer TD, Stern MP, MacCluer JW, Blangero J 1997 A major quantitative trait locus determining serum leptin levels and fat mass is located on human chromosome 2. Nat Genet 15:273-6

21. Hixson JE, Almasy L, Cole S, Birnbaum S, Mitchell BD, Mahaney MC, Stern MP, MacCluer JW, Blangero J, Comuzzie AG 1999 Normal variation in leptin levels in associated with polymorphisms in the proopiomelanocortin gene, POMC. J Clin Endocrinol Metab 84:3187-91

22. Cai G, Cole SA, Bastarrachea-Sosa RA, Maccluer JW, Blangero J, Comuzzie AG 2004 Quantitative trait locus determining dietary macronutrient intakes is located on human chromosome 2p22. Am J Clin Nutr 80:1410-4

23. Hagan MM, Rushing PA, Benoit SC, Woods SC, Seeley RJ 2001 Opioid receptor involvement in the effect of AgRP- (83-132) on food intake and food selection. Am J Physiol Regul Integr Comp Physiol 280:R814-21

24. Koegler FH, Schaffhauser RO, Mynatt RL, York DA, Bray GA 1999 Macronutrient diet intake of the lethal yellow agouti (Ay/a) mouse. Physiol Behav 67:809-12

25. Samama P, Rumennik L, Grippo JF 2003 The melanocortin receptor MCR4 controls fat consumption. Regul Pept 113:85-8 
26. Tung YC, Rimmington D, O'Rahilly S, Coll AP 2007 Pro-opiomelanocortin modulates the thermogenic and physical activity responses to high-fat feeding and markedly influences dietary fat preference. Endocrinology 148:5331-8

27. Cooper SJ, Barber DJ, Barbour-McMullen J 1985 Selective attenuation of sweetened milk consumption by opiate receptor antagonists in male and female rats of the Roman strains. Neuropeptides 5:349-52

28. Candille SI, Kaelin CB, Cattanach BM, Yu B, Thompson DA, Nix MA, Kerns JA, Schmutz SM, Millhauser GL, Barsh GS 2007 A -defensin mutation causes black coat color in domestic dogs. Science 318:1418-23

\section{Figure Legends}

\section{Figure 1. POMC processing}

Upper panel; POMC is a large precursor peptide processed into smaller biologically active fragments by cleavage at cleavage sites (dotted). ACTH, together with $\alpha-, \beta$ - and $\gamma-$ $\mathrm{MSH}$ are together known as the melanocortins. $\mathrm{NT}=\mathrm{N}$-terminal fragment, $\mathrm{JP}=$ joining peptide, $\beta$-LPH $=\beta$-lipotropin, $\beta$-END $=\beta$-endorphin.

Lower panel; the action of melanocortins is mediated through a family of five 7 transmembrane domain $\mathrm{G}$ protein coupled receptors, the melanocortin receptors (MC$\mathrm{R})$.

\section{Figure 2. Pomc insufficiency and fat preference.}

A. Wild type (white bars), Pomc ${ }^{+-}$(gray bars), and Pomc ${ }^{-1-}$ (black bars) were offered a three choice buffet consisting of three different pure macronutrients; fat, carbohydrate and protein. Both $\mathrm{Pomc}^{+/-}$and $\mathrm{Pomc}^{-/-}$consumed more fat than wild-type mice B. When offered a buffet containing sweetened condensed milk, only wild type mice switch preference away from $60 \%$ high fat (menu $1=10 \%, 45 \%, 60 \%$ fat; menu $2=$ sweetened milk $/ 45 \%$ fat, $45 \%, 60 \%$ fat)

(comparison within genotype, "menu 1" vs "menu 2":**, $P<0.01 * * *, P<0.001, \mathrm{n}=6$ per genotype, all mice receiving corticosterone supplemented water) 


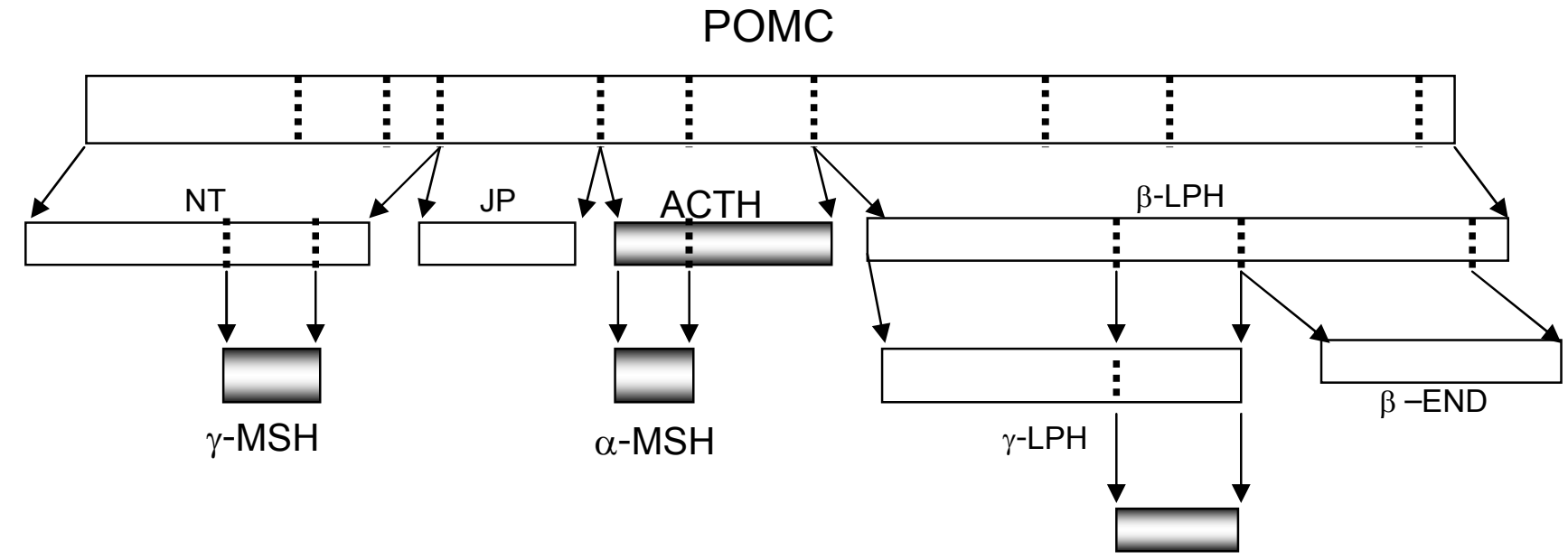

$\beta-\mathrm{MSH}$

\begin{tabular}{c|ccccc}
\hline receptor & MC1-R & MC2-R & MC3-R & MC4-R & MC5-R \\
$\begin{array}{c}\text { site of } \\
\text { expression }\end{array}$ & skin & adrenal cortex & $\begin{array}{c}\text { hypothalamus } \\
\text { thalamus }\end{array}$ & $\begin{array}{c}\text { hypothalamus } \\
\text { brain stem } \\
\text { spinal cord }\end{array}$ & exocrine glands \\
\hline $\begin{array}{l}\text { ligand affinity } \\
\text { at receptor }\end{array}$ & $\alpha>\beta>\gamma>$ ACTH & ACTH & $\gamma=\alpha>\beta$ & $\beta>\alpha>\gamma$ & $\alpha=$ ACTH $>\beta>\gamma$ \\
\hline function & $\begin{array}{c}\text { pigmentation } \\
\text { Immune function }\end{array}$ & steroidogenesis & $\begin{array}{c}\text { sodium homeostasis } \\
\text { energy partitioning }\end{array}$ & $\begin{array}{c}\text { Food intake } \\
\text { Energy expenditure }\end{array}$ & $\begin{array}{c}\text { Sebaceous gland } \\
\text { secretion }\end{array}$
\end{tabular}

Fig 1. Coll \& Tung 
A

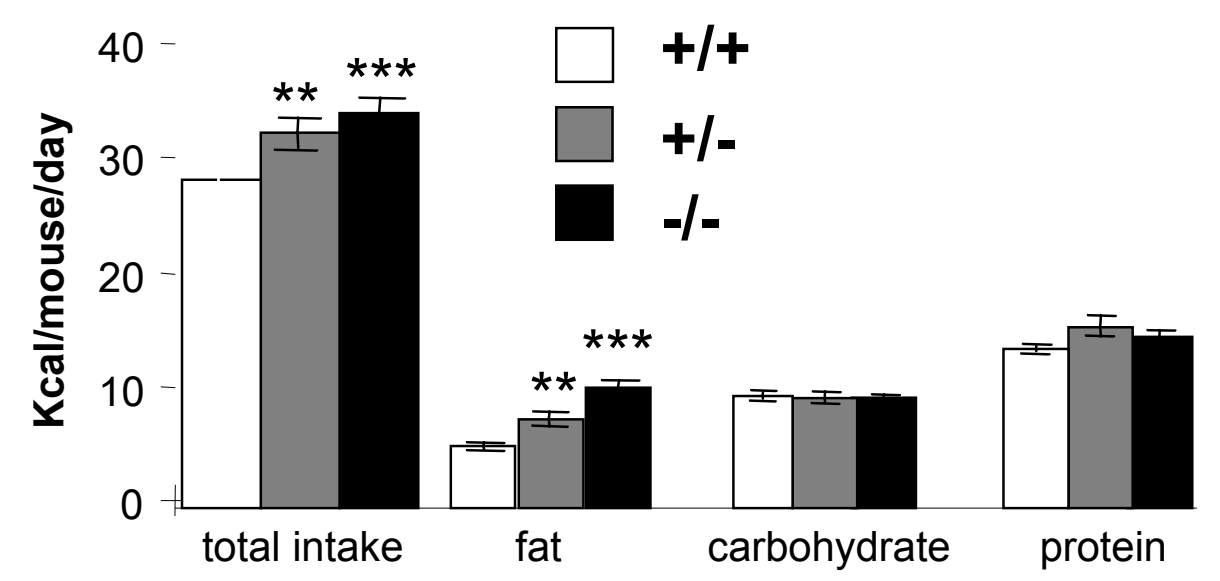

B

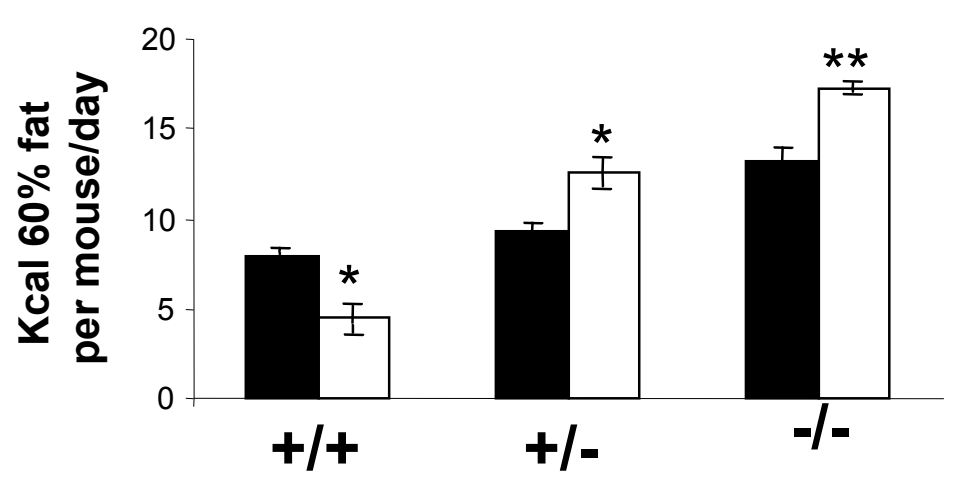

$10 \% / 45 \% / 60 \%$ fat

Fig 2. Coll \& Tung

Sweet milk/45\%/60\% fat 